\title{
Bioconversion Studies of Methyl Laurate to Dodecanedioic Acid using a Wild-type of Candida tropicalis
}

\author{
Rifkah Akmalina, Ronny Purwadi, and Johnner Sitompul* \\ Chemical Engineering Department, Institut Teknologi Bandung, Jl. Ganesha 10, Bandung, 40132, Indonesia
}

\begin{abstract}
Production of dodecanedioic acid (DDDA), a platform chemical used as raw material for various commodities and polymers, has been studied through a biological process. This process was conducted by using a wild-type of Candida tropicalis which can be obtained easily from natural resources. The aim of this research was to study the characteristics of DDDA production from methyl laurate through batch fermentation process. Growth phase was carried out for $20 \mathrm{~h}$, as the beginning of fermentation, then continued to conversion phase for 5 until 6 days. Utilization of methyl laurate and production of DDDA were analysed using gas chromatography, which proved the ability of $C$. tropicalis in assimilating methyl laurate to convert it become DDDA. The highest value of cells yield $\left(\mathrm{Y}_{\mathrm{x} / \mathrm{s}}\right)$ and DDDA yield $\left(\mathrm{Y}_{\mathrm{p} / \mathrm{s}}\right)$ successfully obtained were $0.86 \mathrm{~g}$ cells $/ \mathrm{g}$ methyl laurate and $0.20 \mathrm{~g}$ DDDA $/ \mathrm{g}$ methyl laurate, respectively. This study also showed the possibility of fermentation products accumulation as intermediate, or accumulation of DDDA inside the cells. Thus, this study can be applied as an alternative in addition to the use of mutant microorganism in producing DDDA.
\end{abstract}

\section{Introduction}

The long-chain dicarboxylic acids are well known platform chemicals for production of various commodities, such as polymers, perfumes, hot-melting adhesives, and high quality lubricants [1-2]. Dodecanedioic acid (DDDA) is one of dicarboxylic acids produced excessively ( $>40$ million pounds per year) [3]. Currently, crude oil-based DDDAs are still used widely as raw material for polymer production, for example nylon which is produced from crude oil through several steps of chemical reaction [4]. These include limitations in complicated process, generation of unwanted and hazardous byproducts, also dependence on non-renewable petrochemical feedstock [1]. The use of crude oil-based compounds continuously will generate following problem when oil feedstock starts decreasing. A substitution of petrochemical with bio-based synthesis routes is one of alternative [4]. Thus, biotechnology based on renewable resources becomes an interesting process, for example by using fatty acids as raw material.

Several works for dicarboxylic acids production have been studied, with the raw materials or substrates used depend on the long chain of dicarboxylic acid desired. Dodecane [5-6] and lauric acid [7] were widely used as substrates for DDDA production. A direct comparison between utilization of alkanes and fatty acids as substrates has not been studied in detail. Moreover, the use of methyl ester of lauric acid is still rarely conducted. Hence, this study will compare utilization of alkane and fatty acid methyl ester, in particular dodecane and methyl laurate as substrates in the production of DDDA.

In biological process, the success of dicarboxylic acid production really depends on the microorganisms used. Most of dicarboxylic acids could be produced by utilizing genetically engineered (mutant) microorganisms, for example Candida tropicalis 7/34 [6], C. tropicalis CGMCC 356 [2], C. cloacae MR-12 [8], and C. cloacae FERM-P736 [7]. A sophisticated and complicated methods or technologies are needed to obtain mutant microorganisms. In the other hand, there is no research found that elucidate clearly the use of wildtype microorganism for producing dicarboxylic acid, especially DDDA. Whereas, a-wild-type yeast can be easily obtained from natural resources, e.g. palm kernel oil, palm fiber oil, and ambarella fruit. Thus, this work was performed to study the characteristics of wild-type C. tropicalis in producing DDDA on dodecane and methyl laurate substrates in general. In this paper, there is also a brief explanation about mechanism of substrate

\footnotetext{
Corresponding author: sitompul@che.itb.ac.id
} 
oxidation for producing dicarboxylic acid. Then it can be related to the result of this work for defining more about DDDA production.

\section{Experimental}

\subsection{Materials}

Methyl laurate ( $>60 \%$ purity) was obtained from chemical conversion of palm kernel oil. n-Dodecane (99\% purity) was a general purpose reagent and obtained from BDH Chemicals Ltd. Poole England. The strain of C. tropicalis wild-type was isolated from ambarella fruit without any treatment of mutation.

\subsection{Cells cultivation}

One loop of C. tropicalis grown on potato dextrose agar (PDA) slant was transferred into $50 \mathrm{ml}$ of preculture medium containing $1 \%$ yeast extract, $2 \%$ peptone, and $2 \%$ glucose. Inoculum was incubated for $24 \mathrm{~h}$ at $30^{\circ} \mathrm{C}$ in a shaking incubator at $150 \mathrm{rpm}$.

Growth phase was started by transferring $15 \mathrm{ml}$ of inoculum to a 500-ml conical flask containing $150-\mathrm{ml}$ medium which had the following composition per litre: 5 g glucose, $2 \mathrm{~g}\left(\mathrm{NH}_{4}\right)_{2} \mathrm{SO}_{4}, 2 \mathrm{~g} \mathrm{NH}_{4} \mathrm{NO}_{3}, 1 \mathrm{~g} \mathrm{~K}_{2} \mathrm{HPO}_{4}, 1.5$ g $\mathrm{KH}_{2} \mathrm{PO}_{4}, 1.5 \mathrm{~g} \mathrm{Na}_{2} \mathrm{HPO}_{4} .2 \mathrm{H}_{2} \mathrm{O}, 0.2 \mathrm{~g} \mathrm{MgSO}_{4} .7 \mathrm{H}_{2} \mathrm{O}$, $0.2 \mathrm{~g} \mathrm{KCl}, 4 \mathrm{mg} \mathrm{ZnSO} 4.7 \mathrm{H}_{2} \mathrm{O}, 4 \mathrm{mg} \mathrm{FeSO}_{4} .7 \mathrm{H}_{2} \mathrm{O}$, and $10 \mathrm{~g}$ yeast extract. The culture was aerobically grown at $30^{\circ} \mathrm{C}, 150 \mathrm{rpm}$ in a shaking incubator. Cultivation was carried out until the beginning of stationary phase.

\subsection{Dodecanedioic acid production}

Methyl laurate was added into the culture at the beginning of conversion phase, followed by the addition of tween $80(0.01 \% \mathrm{v} / \mathrm{v})$. Medium $\mathrm{pH}$ was raised to 8.0 by adding $1 \mathrm{~N} \mathrm{NaOH}$ and maintained using phosphate buffer. Fermentation process was continued for 5 until 6 days at $30^{\circ} \mathrm{C}$ in a shaking incubator at $150 \mathrm{rpm}$.

Samples $(6 \mathrm{ml})$ were taken manually at regular intervals. Analysis of cells concentration, methyl laurate consumption, and DDDA production was carried out for each sample by these following methods.

\subsection{Analysis}

Cell growth was determined by measuring of the turbidity. Samples $(0.5 \mathrm{ml})$ were $10 \mathrm{x}$ diluted and measured using UV-vis spectrophotometer at $600 \mathrm{~nm}$. The absorbance data obtained were calibrated with cell dry weight data. Fermentation samples $(5 \mathrm{ml})$ were centrifuged at $5000 \mathrm{rpm}, 5^{\circ} \mathrm{C}$ for $10 \mathrm{~min}$. The precipitated cells were dried in oven at $100^{\circ} \mathrm{C}$, and weighted.

Glucose concentration in growth phase was measured by phenol-sulphuric method. To $1 \mathrm{ml}$ of diluted free-cell samples, $1 \mathrm{ml}$ of $5 \%$ phenol solution and $5 \mathrm{ml}$ of $95-97 \% \mathrm{H}_{2} \mathrm{SO}_{4}$ were added respectively. The absorbance of the solution was measured using UV-vis spectrophotometer after $10 \mathrm{~min}$ at $488 \mathrm{~nm}$, and the data were compared with calibration curve of glucose standard solution.

Methyl laurate consumed was determined by gas chromatography (GC). A half $\mathrm{ml}$ of free-cell samples was extracted using $1 \mathrm{ml}$ of hexane. The mixture was centrifuged at $5000 \mathrm{rpm}, 25^{\circ} \mathrm{C}$ for $5 \mathrm{~min}$. Aliquot taken from organic phase was injected into a Shimadzu gas chromatograph. The operating conditions were as follow: injection temperature of $280^{\circ} \mathrm{C}$, FID-detector temperature of $300^{\circ} \mathrm{C}$, and quartz capillary column coated with RTX-5 (crossbond ${ }^{\circledR} \quad 5 \%$ diphenyl/95\% dimethyl polysiloxane). Initial column temperature was set at $70^{\circ} \mathrm{C}$ for $3 \mathrm{~min}$, followed by $35^{\circ} \mathrm{C} / \mathrm{min}$ temperature increase to $210^{\circ} \mathrm{C}$, followed by $3^{\circ} \mathrm{C} / \mathrm{min}$ temperature increase to $240^{\circ} \mathrm{C}$ with helium carrier gas and column flow of $1 \mathrm{ml} / \mathrm{min}$.

DDDA produced from fermentation process was also determined by GC. To $0.25 \mathrm{ml}$ of free-cell samples added $0.25 \mathrm{ml}$ of $6 \mathrm{~N} \mathrm{H}_{2} \mathrm{SO}_{4}$. DDDA then was extracted into $1 \mathrm{ml}$ of diethyl ether. The mixture was centrifuged at $5000 \mathrm{rpm}, 25^{\circ} \mathrm{C}$ for $5 \mathrm{~min}$. An aliquot of $200 \mu \mathrm{l}$ from organic phase was transferred to eppendorf tube, followed by the addition of BSTFA $(100 \mu \mathrm{l})$ for silylation process. Aliquot from the mixture was injected into a Shimadzu gas chromatograph with these following operating conditions: injection temperature of $300^{\circ} \mathrm{C}$, column coated with RTX-5 (crossbond ${ }^{\circledR} \quad 5 \%$ diphenyl $/ 95 \%$ dimethyl polysiloxane), temperature of $190^{\circ} \mathrm{C}$ (hold for $30 \mathrm{~min}$ ) with helium carrier gas and column flow of $1 \mathrm{ml} / \mathrm{min}$, and FID-detector temperature of $250^{\circ} \mathrm{C}$.

\section{Results and discussion}

\subsection{Growth phase of fermentation}

When $C$. tropicalis is grown in a medium containing glucose as a carbon source, there was a significant increase in cell concentration. The highest concentration was reached at 20 -h-cultivation which produced about $2.8 \mathrm{~g}$ dry biomass/l. Further cultivation until $24 \mathrm{~h}$ resulted in an equal value, indicating a stationary phase of cell growth (Fig. 1).

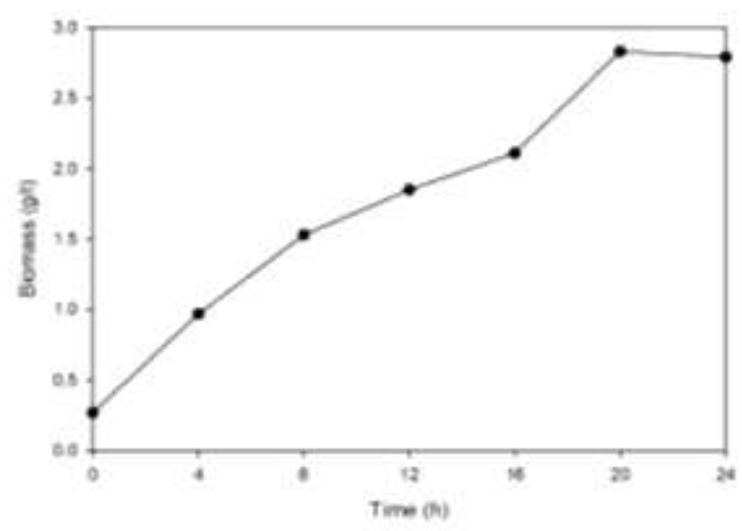

Fig. 1. Cell growth of $C$. tropicalis in medium containing glucose as a carbon source 
Table 1. Growth phase in several studies using different medium and carbon source

\begin{tabular}{|c|c|c|c|c|}
\hline Yeast & Medium composition & Carbon source & Growth phase & References \\
\hline $\begin{array}{l}\text { C. tropicalis } \\
\text { (wild-type) }\end{array}$ & $\begin{array}{l}\left(\mathrm{NH}_{4}\right)_{2} \mathrm{SO}_{4}, \mathrm{NH}_{4} \mathrm{NO}_{3}, \mathrm{~K}_{2} \mathrm{HPO}_{4}, \mathrm{KH}_{2} \mathrm{PO}_{4}, \\
\mathrm{Na}_{2} \mathrm{HPO}_{4} .2 \mathrm{H}_{2} \mathrm{O}, \mathrm{MgSO}_{4} .7 \mathrm{H}_{2} \mathrm{O}, \mathrm{KCl}, \mathrm{ZnSO}_{4} .7 \mathrm{H}_{2} \mathrm{O} \text {, } \\
\mathrm{FeSO}_{4} .7 \mathrm{H}_{2} \mathrm{O} \text {, yeast extract }\end{array}$ & Glucose & $20 \mathrm{~h}$ & This work \\
\hline $\begin{array}{l}\text { C. tropicalis } \\
\text { ATCC } 20987\end{array}$ & $\begin{array}{l}\left(\mathrm{NH}_{4}\right)_{2} \mathrm{SO}_{4}, \mathrm{~K}_{2} \mathrm{HPO}_{4}, \mathrm{KH}_{2} \mathrm{PO}_{4} \text {, corn steep liquor, } \\
\mathrm{MgSO}_{4}, \mathrm{NaCl}, \mathrm{CaCl}_{2}\end{array}$ & Glucose & $18 \mathrm{~h}$ & [3] \\
\hline C. tropicalis $7 / 34$ & $\begin{array}{l}\left(\mathrm{NH}_{4}\right)_{2} \mathrm{SO}_{4}, \mathrm{NH}_{4} \mathrm{NO}_{3}, \mathrm{~K}_{2} \mathrm{HPO}_{4}, \mathrm{KH}_{2} \mathrm{PO}_{4}, \\
\mathrm{Na}_{2} \mathrm{HPO}_{4} . \mathrm{H}_{2} \mathrm{O}, \mathrm{MgSO}_{4} .7 \mathrm{H}_{2} \mathrm{O}, \mathrm{KCl}, \mathrm{MnCl}_{2} \text {, } \\
\mathrm{ZnSO}_{4} .7 \mathrm{H}_{2} \mathrm{O}, \mathrm{FeSO}_{4} .7 \mathrm{H}_{2} \mathrm{O} \text {, corn steep liquor, } \\
\text { polypropylene glycol }\end{array}$ & Glycerol & $24 \mathrm{~h}$ & [6] \\
\hline $\begin{array}{l}\text { C. tropicalis } \\
\text { CGMCC } 356\end{array}$ & $\begin{array}{l}\text { Yeast extract, corn steep liquor, urea, } \mathrm{KH}_{2} \mathrm{PO}_{4} \text {, } \\
\mathrm{CH}_{3} \mathrm{COONa}, \mathrm{NaCl}, \mathrm{MgSO}_{4} .7 \mathrm{H}_{2} \mathrm{O} \text {, polypropylene glicol }\end{array}$ & Sucrose & $18 \mathrm{~h}$ & [2] \\
\hline
\end{tabular}

Growth phase in fermentation process aims to increase cells amount, so that a carbon source which can be easily utilized by microorganism is needed. Glucose is one of carbon source that frequently used for yeast growth [9]. In line with the result given by this study, it showed that glucose was an appropriate carbon source used for increasing cell concentration.

Growth phase can be carried out in slightly different times. It depends on medium composition, type and amount of carbon source, also type of yeast used in fermentation, as shown in Table 1. In general, a mutant and wild-type of $C$. tropicalis have the same capability in assimilating sugar.

\subsection{Growth on dodecane and methyl laurate}

Candida tropicalis grown in dodecane and methyl laurate resulted in a different tendency. Those substrates could be assimilated and converted into cells (biomass). At the beginning of substrates addition, there was a decrease in cell concentration, indicating an adaptation phase of cell growth (Fig. 2). Microorganisms need to rearrange their enzyme to assimilate dodecane or methyl laurate after assimilating glucose as carbon source. A significant growth was shown after 24-h-fermentation in both substrates, but further fermentation until $72 \mathrm{~h}$ showed that $C$. tropicalis could assimilate methyl laurate better than dodecane.

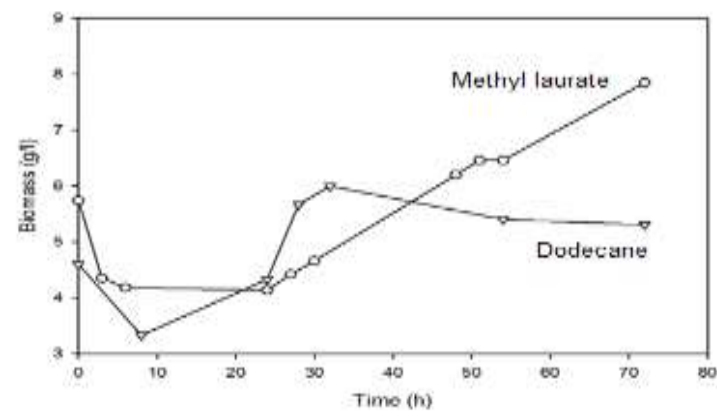

Fig. 2. Growth of C. tropicalis in dodecane and methyl laurate during 72-h-fermentation with substrates concentration of 5\% $\mathrm{v} / \mathrm{v}$ respectively
Dodecane is a long-chain alkane that supplies carbon source alternative for growth, while short-chain alkanes can be toxic that inhibit the yeast growth [7]. In addition, short-chain fatty acids can also inhibit the growth of microorganisms by disturbing basal cell functions [10]. The results shown in Fig. 2 are in an agreement with the theories above, in which dodecane and methyl laurate were able to be used as substrates for growth.

However, consumption rate of methyl laurate by $C$. tropicalis was faster than dodecane. It can be seen from Fig. 2 that until $72 \mathrm{~h}$ fermentation was carried out, cell concentration kept increasing significantly with methyl laurate as substrate. This study also proved that the use of fatty acid methyl ester (FAME) did not inhibit cell growth. It is presumably because the concentration of methanol contained in FAME is relatively low, so that it supplies more carbon source for yeast growth.

By using dodecane as substrate, the highest cell concentration attained was $6.0 \mathrm{~g}$ dry biomass/1 at 32-hfermentation. Further fermentation showed a gradual decrease in cell amount because there was insufficient carbon source to be consumed afterwards.

Theoretically, dicarboxylic acids can be produced from alkanes and fatty acids. Alkanes were oxidized into fatty alcohols, fatty aldehydes, and fatty acids. Further oxidation of fatty acids will produce dicarboxylic acids [11]. This study showed that biooxidation of alkanes was slower than biooxidation of fatty acids, indicating that oxidation step of alkanes into fatty acids was a rate limiting step. Using methyl laurate as substrate can accelerate oxidation process for producing DDDA, which is more advantageous than using dodecane as substrate.

\subsection{Production of dodecanedioic acid}

Growth of $C$. tropicalis was initially analysed in methyl laurate with concentration of $5 \mathrm{~g} / 1,10 \mathrm{~g} / \mathrm{l}$, and $15 \mathrm{~g} / \mathrm{l}$. In general, $C$. tropicalis was able to assimilate methyl laurate in various concentrations and convert it into biomass. At the end of fermentation process, there was a little amount of methyl laurate remained in medium: 0.5, 1.6, and $2.1 \mathrm{~g}$ methyl laurate/1 from the initial concentration, respectively (Fig. 3). Theoretically, the 

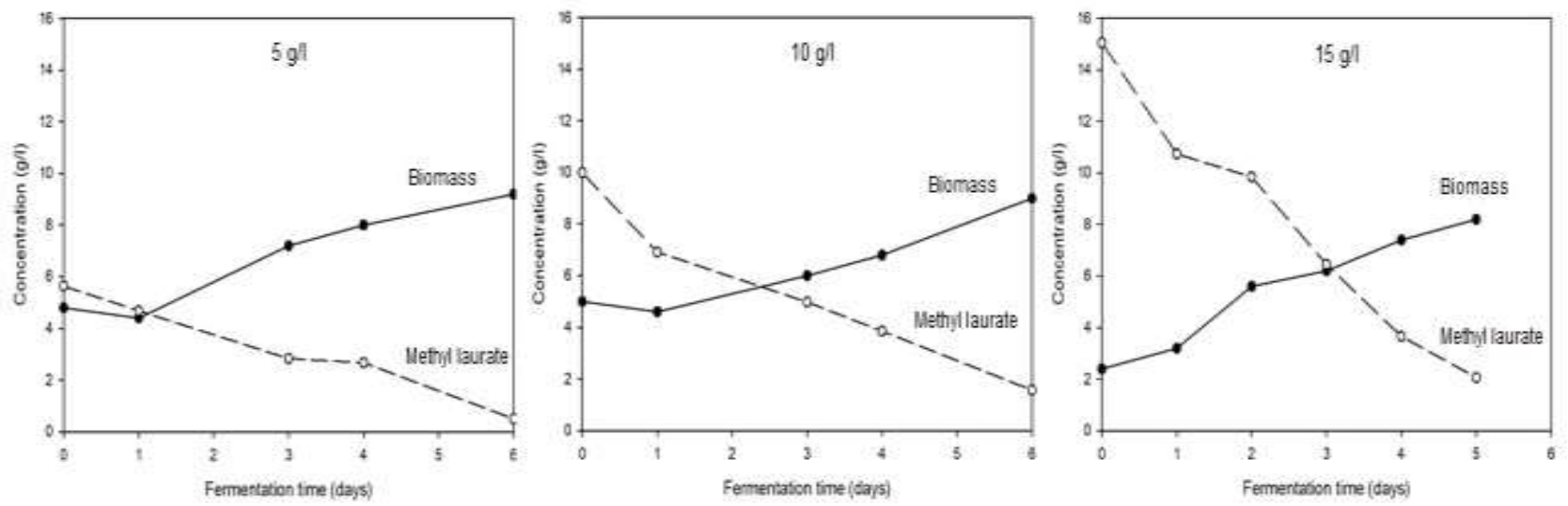

Fig. 3. Assimilation of methyl laurate in various concentrations with the production of biomass

Table 2. Biomass and product yield from various concentrations of methyl laurate

\begin{tabular}{|l|c|c|c|}
\hline \multirow{2}{*}{ Parameters } & \multicolumn{3}{|c|}{ Initial concentration of methyl laurate } \\
\cline { 2 - 4 } & $\mathbf{5} \mathbf{g} / \mathbf{l}$ & $\mathbf{1 0} \mathbf{g} / \mathbf{l}$ & $\mathbf{1 5} \mathbf{g} / \mathbf{l}$ \\
\hline $\begin{array}{l}\text { Yx/s }(\mathrm{g} \text { cells/g } \\
\text { methyl laurate) }\end{array}$ & 0.86 & 0.48 & 0.45 \\
\hline $\begin{array}{l}\text { Yp/s (g DDDA/g } \\
\text { methyl laurate) }\end{array}$ & 0.20 & 0.11 & 0.08 \\
\hline
\end{tabular}

more methyl laurate consumed, the more biomass produced. In actual, the biomass produced was relatively equal among three variations of concentration (Table 2).

The equal value of biomass yield indicates other products that might also be produced. There was a probability for DDDA produced from fermentation process. Further analysis was conducted to prove the ability of wild-type $C$. tropicalis in producing DDDA. Gas chromatography analysis showed the existence of DDDA in fermentation broth as shown in Fig. 4.

DDDA produced from various concentrations of methyl laurate was relatively equal as fermentation time prolonged (Fig. 4). The highest DDDA concentration that successfully attained was only $1 \mathrm{~g} / 1$ in approximate. Relating this result with assimilation data shown in Fig. 3 have not yet answered the question related to products obtained beside of biomass. More DDDA should be produced as more methyl laurate was consumed.

When n-dodecane used as a substrate for producing DDDA, 12-hydroxydodecanoic acid, n-dodecanol, and n-dodecanoic acid were excreted and detected in the medium [5] as intermediate products. In this study, fatty acid was used as a substrate. There is a possibility of fermentation products accumulated in the form of hydroxy-fatty acid and fatty acid aldehyde as intermediate products of fatty acid oxidation. Hence, there was insufficient DDDA accumulated in fermentation broth.

Another possibility related to the process occurred in utilization of a wild-type of $C$. tropicalis is the accumulation of DDDA inside the cells (DDDA as intracellular product). This phenomenon might cause in low DDDA concentration in fermentation broth, as shown in Fig. 4. The use of mutant strain successfully

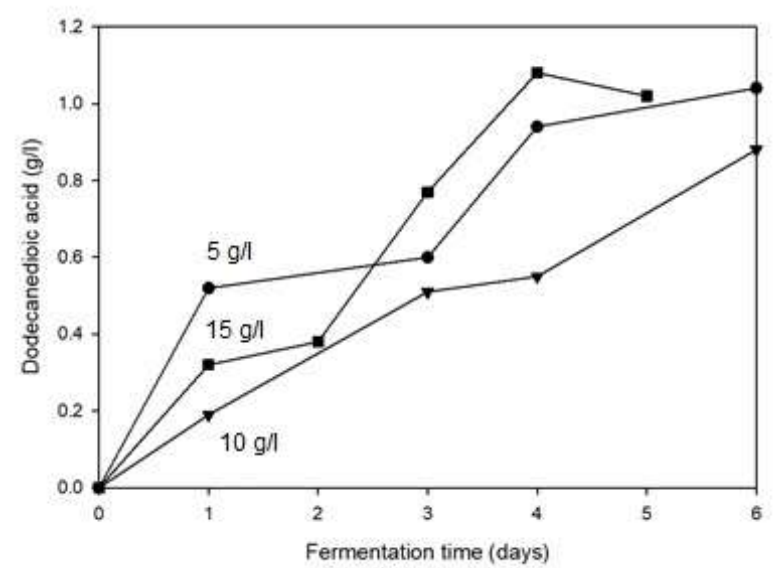

Fig. 4. Dodecanedioic acid produced from several concentrations of methyl laurate

improved the ability to produce and secrete dicarboxylic acid through cell membrane [12]. Extracellular $\mathrm{pH}$ is a factor influencing acid secretion. In a higher $\mathrm{pH}$, cells had to secrete more acid to neutralize $\mathrm{OH}^{-}$in order to maintain the micro-environment balance inside cells [12]. The appropriate $\mathrm{pH}$ adjustment is important to make secretion process becomes effective while using a wild-type microorganism.

Comparing biomass and DDDA yield (Table 2), the amount of biomass was about four times higher than DDDA. In other word, methyl laurate was converted to biomass more than DDDA.

Several studies had successfully proved that mutant microorganisms were able to produce dodecanedioic acid (Table 3). Compared with this study, the use of mutant microorganism resulted in higher yield of DDDA in shorter fermentation time. DDDA yield of $0.20 \mathrm{~g} / \mathrm{g}$ methyl laurate was obtained in 144-h-fermentation from this study. It means that the use of mutant yeast was more advantageous because the fermentation process was more effective than the use of wild-type yeast. 
Table 3. Comparison of DDDA yield from several researches using mutant yeasts

\begin{tabular}{|c|c|c|c|c|}
\hline Substrate & Microorganism & Fermentation time & Yield (g DDDA/g substrate) & References \\
\hline Dodecane & C. tropicalis $7 / 34$ & $48 \mathrm{~h}$ & 0.91 & [6] \\
\hline Dodecane & C. tropicalis CGMCC 356 & $120 \mathrm{~h}$ & 0.73 & [2] \\
\hline \multirow[t]{4}{*}{ Dodecane } & \multirow{4}{*}{ C. cloacae MR-12 } & $48 \mathrm{~h}$ & 0.26 & \multirow{4}{*}{ [8] } \\
\hline & & $72 \mathrm{~h}$ & 0.41 & \\
\hline & & $48 \mathrm{~h}$ & 0.20 & \\
\hline & & $72 \mathrm{~h}$ & 0.29 & \\
\hline Dodecane & \multirow[t]{2}{*}{ C. cloacae FERM-P736 } & \multirow[t]{2}{*}{$72 \mathrm{~h}$} & 0.20 & \multirow[t]{2}{*}{ [7] } \\
\hline Lauric acid & & & 0.28 & \\
\hline \multirow[b]{2}{*}{ Dodecane } & \multirow[b]{2}{*}{ C. tropicalis $\mathrm{S}-76$} & $36 \mathrm{~h}$ & 0.23 & \multirow[t]{2}{*}{ [5] } \\
\hline & & $48 \mathrm{~h}$ & 0.28 & \\
\hline
\end{tabular}

\subsection{Mechanism of Fatty Acid Oxidation}

The alkane or fatty acid metabolism of $C$. tropicalis is divided into three steps [12]: (1) substrate uptake, (2) metabolism of substrate in C. tropicalis cells, and (3) secretion of dicarboxylic acid. Substrate uptake into the cell is the first important step before starting oxidation process. In this study, tween 80 was used as surfactant to emulsify methyl laurate into fermentation medium, thus reducing mass transfer limitation between methyl laurate and aqueous phase of medium.

The different result obtained from using mutant and wild-type yeast in producing DDDA was related to the oxidation mechanism of substrate used. A reaction of $\beta$ oxidation might cause in low yield of DDDA when using wild-type $C$. tropicalis in fermentation process.

Fatty acids can be oxidized through reactions of $\beta$ oxidation, $\alpha$-oxidation, and $\omega$-oxidation. Beta-oxidation, which produces acetyl-CoA in peroxisome is the main reaction of fatty acid oxidation. Further oxidation of acetyl-CoA through citric acid cycle generates $\mathrm{CO}_{2}$, and energy in the form of ATP is produced through oxidative phosphorylation (Fig. 5) [13].

In biological process of dicarboxylic acid production, $\omega$-oxidation is more desired, but it occurs in small amount. Methyl group of fatty acid is hydroxylated into $\omega$-hydroxy-fatty acid. Further oxidation of that compound leads to the production of fatty acid aldehyde and dicarboxylic acid (Fig. 5) [11,13]. Dicarboxylic acids produced from this reaction are only intermediate compounds, and will further be degraded by $\beta$-oxidation resulting in shorter-chain dicarboxylic acids.

Naturally, a wild-type yeast will oxidize fatty acids through $\beta$-oxidation reaction. This reaction is avoided in dicarboxylic acid production due to $\mathrm{CO}_{2}$ and energy generation as the main product, so that insufficient amount of dicarboxylic acids is accumulated in fermentation broth.

A genetic engineering through deletion of genes involved in $\beta$-oxidation and overexpression of $\omega$ oxidation enzyme can be applied to block $\beta$-oxidation and make $\omega$-oxidation as the main pathway for fatty acid oxidation, resulting high yield of dicarboxylic acids $[11,14]$.

Genetically engineered microorganisms might also have improved ability to secrete dicarboxylic acids produced from oxidation process [12], so that dicarboxylic acids could be obtained easily from fermentation broth in sufficient amount. In contrast, a wild-type microorganism needs distinctive condition to make an effective secretion process, for instance by raising extracellular $\mathrm{pH}$ [12]. As a result, there are differences in DDDA yield by using mutant and wildtype microorganisms as shown in Table 3.

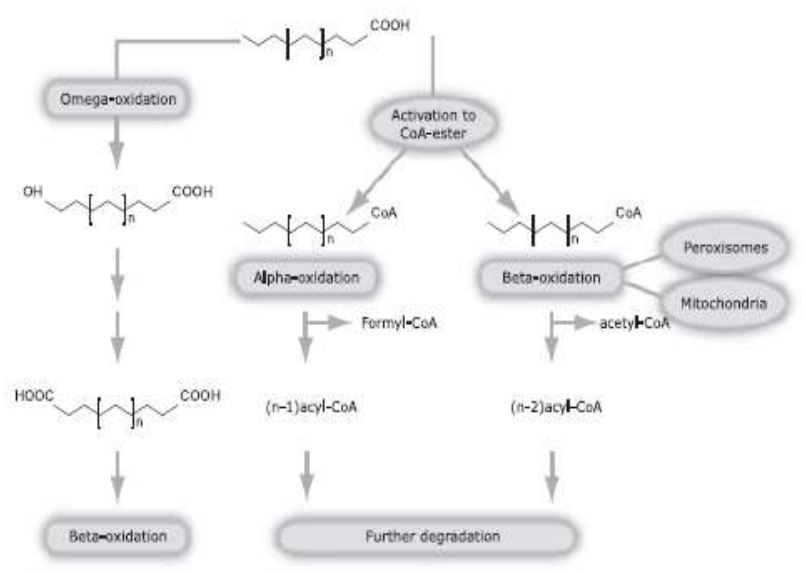

Fig. 5. Mechanism of fatty acid oxidation [15]

\section{Conclusions}

This study has shown that a wild-type of Candida tropicalis is able to produce dodecanedioic acid from methyl laurate. However, the amount of DDDA produced is less than the use of mutant yeast. In addition, dodecane can also be used as a substrate for DDDA production. However, cell growth analysis indirectly showed that oxidation of dodecane was slower than oxidation of methyl laurate.

Various concentrations of methyl laurate used in fermentation process do not affect the biomass and DDDA yield. The possibility of fermentation products accumulation in the form of hydroxy-fatty acid and fatty acid aldehyde may cause the low yield of DDDA. Hence, it is important to do further analysis of compounds contained in fermentation broth using gas chromatography-mass spectrometry (GC-MS). In the other hand, DDDA may also be accumulated inside the cells. Using wild-type microorganisms did bring the disadvantage of poor DDDA secretion from the cells, so that $\mathrm{pH}$ adjustment should be performed well to improve the ability of secretion process. Moreover, an experiment 
for disrupting cells can also be carried out to obtain more DDDA from the cells.

In general, using mutant microorganisms gives more advantages than using a wild-type one. It is related to $\beta$ oxidation reaction that may occur, which also produce $\mathrm{CO}_{2}$ and energy as main metabolism products of wildtype microorganisms. However, this preliminary study could be useful for the following research and might be applied as an alternative in addition to the use of mutant microorganism in producing DDDA.

This work was financially supported by Korea Research Institute of Bioscience and Biotechnology (KRIBB).

\section{References}

1. C.S. Prabu, S.K. Lee, J. Agric. Food Chem. 63, 8199-8208 (2015)

2. S. Li, C. Li, X. Fang, Z. Cao, Enzyme Microb. Technol. 34, 73-77 (2004)

3. D.P. Mobley, Biosynthesis of Long-Chain Dicarboxylic Acid Monomers from Renewable Resources (Final Technical Report, United States, 1999)

4. N. Ladkau, M. Assmann, M. Schrewe, M.K. Julsing, A. Schmid, B. Buhler, Metab. Eng. (2016)
5. Z. Yi, H. Rehm, European J. Appl. Microbiol. Biotechnol. 14, 254-258 (1982)

6. F.F. Hill, I. Venn, K.L. Lukas, Appl. Microbiol. Biotechnol. 24, 168-174 (1986)

7. K.D. Green, M.K. Turner, J.M. Woodley, Enzyme Microb. Technol. 27, 205-211 (2000)

8. R. Uchio, I. Shiio, Agr. Biol. Chem. 36, 426-433 (1972)

9. M. Saghbini, D. Hoekstra, J. Gautsch, Methods in Molecular Biology, Two-Hybrid Systems (2001)

10. Z. Hunkova, Z. Fencl, Biotechnol. Bioeng. 29, 1623-1641 (1977)

11. S. Huf, S. Krugener, T. Hirth, S. Rupp, S. Zibek, Eur. J. Lipid Sci. Technol. 113, 548-561 (2011)

12. R. Lin, Z. Cao, T. Zhu, Z. Zhang, Biop. Eng. 22, 391-396 (2000)

13. D. Voet, J.G. Voet, C.W. Pratt, Fundamentals of Biochemistry (John Wiley and Sons, England, 2016)

14. P.C. Williams, Biological Conversion of Alkanes to Dicarboxylic Acids (University of Cape Town, 2005)

15. J.A. Wanders, J. Komen, S. Kemp, The FEBS Journal 278, 182-194 (2011) 